Table 2

\begin{tabular}{|l|c|c|c|}
\hline & \multicolumn{2}{|c|}{ No. of plants in $F_{2}$ segregation } \\
\hline Observed & Sensitive & Day-neutral & Total \\
\hline Expected on 3:1 ratio & 666 & 216 & 882 \\
& $661 \cdot 5$ & $220 \cdot 5$ & 882 \\
\hline
\end{tabular}

$\chi^{2}=0.122 ; P=0.95-0.50$

plants with a white apiculus is illustrated in the graph. The observed numbers of plants in the $F_{2}$ classes and the expectations based on independence are given in Table 3.

Table 3

\begin{tabular}{|c|c|c|c|c|c|}
\hline & \multicolumn{5}{|c|}{ No. of plants in $F_{2}$ segregation } \\
\hline & $\begin{array}{c}\text { Sensitive, } \\
\text { apiculus. } \\
\text { purple }\end{array}$ & $\begin{array}{l}\text { Sensitive, } \\
\text { apiculus } \\
\text { white }\end{array}$ & $\begin{array}{l}\text { Day- } \\
\text { neutral, } \\
\text { apiculus } \\
\text { purple }\end{array}$ & $\begin{array}{l}\text { Day- } \\
\text { neutral, } \\
\text { apiculis } \\
\text { white }\end{array}$ & Total \\
\hline $\begin{array}{l}\text { Observed } \\
\text { Expected }\end{array}$ & 470 & 196 & 211 & 5 & 882 \\
\hline ratio & $496 \cdot 1$ & $165 \cdot 4$ & $165 \cdot 4$ & $55 \cdot 1$ & 882 \\
\hline
\end{tabular}

The cross-over value for the two pairs of genes estimated from the $F_{2}$ is $16 \cdot 3 \pm 3 \cdot 26$ per cent.

Photoperiod sensitivity showed similar $F_{2}$ segregation and linkage with apiculus colour in crosses with $H M C 12$.

A full account of this work will be published elsewhere.

Department of Agriculture,

M. F. Chandraratina

Peradeniya, Ceylon. Nov. 11.

\section{Contamination of Azotobacter chroococcum by Gram-negative Bacterial Rods}

IN a recent investigation, it proved virtually impossible to obtain a pure culture of Azotobacter chroococcum. After initial isolation from soil in flasks containing 2 per cent mannitol and 0.02 per cent sodium phosphate in tap water, progressive subcultures were made on solid nitrogen-free medium containing washed agar and the same percentages of mannitol and phosphate in distilled water-a recognized procedure for purifying Azotobacter ${ }^{1}$. Characteristic colonies of Azotobacter were obtained in about a month, and stained smear preparations of these colonies revealed only the characteristic large cells of the organism. If, however, colonies were inoculated into peptone water (in which Azotobacter will not grow ${ }^{2}$ a faint haze due to growth of small Gram-negative rods appeared after $24-48 \mathrm{hr}$. incubation at $22^{\circ} \mathrm{C}$. A more abundant growth of these rods was obtained in $24 \mathrm{hr}$. on nutrient agar containing 0.1 per cent whole milk, whereas on this medium the growth of Azotobacter was very poor after three to four days. Subculture of Azotobacter on solid nitrogen-free medium (above) was therefore extended up to periods of four months, and $0 \cdot 1$ per cent sodium silicate, 0.002 per cent iron $\left(\mathrm{FeCl}_{3}\right)$ and boron, 0.00004 per cent sodium molybdate, soil extract and hay-infusion were incorporated in some cultures to heighten the resistance of Azotobacter. In practically all cases, however, the contamination persisted. On the one or two occasions on which it appeared to be absent, growth of Azotobacter was very poor, marked by absence of the characteristic mucilage, and ceased within seven to fourteen days; nor could it be restored by incorporation of any of the above substances. Fourteen strains of contaminants were isolated the cultural characters of which proved conclusively they were not pleomorphic forms of Azotobacter, the majority being strains of Pseudomonas (fluorescent and non-fluorescent) with one or two species of Achromobacter. In the absence of Azotobacter, they grow well up to four weeks in flasks of the above liquid mannitol medium, reducing its reaction to a $p \mathrm{H}$ of 4.0 in a fortnight although growth was still vigorous. Their source of nitrogen in such cultures is obscure. They grew in liquid media, distilled water with 1 per cent glucose and ammonia (0.1 per cent $\left(\mathrm{NH}_{4}{ }_{2} \mathrm{HPO}_{4}\right)$ as the sole source of nitrogen; but only feebly in 1 per cent glucose only. Incorporation of whole killed cultures, extracts or filtrates of cultures improved growth of Azotobacter on solid nitrogen-free media and improved its mucilage production.

Large numbers of contaminants depressed the growth of Azotobacter in nitrogen-free liquid media when they were grown in association. Fluorescent strains of Pseudomonas destroyed the Azotobacter cells.

All the contaminants were freely ingested by soil ciliate protozoa which multiplied in their presence. Fluorescent Pseudomonas inhibited growth of Colpoda sp. but not, for example, Urostyla grandis, which fed upon it.

Azotobacter is reported to be accompanied in Nature by a small Gram-negative rod Radiobacter the relationships of which are ill-defined. The present findings suggest that association with common Gramnegative rods may persist unsuspected in laboratory cultures regarded as pure.

These observations were carried out when I was serving as senior bacteriologist in the National Agricultural Advisory Service of the Ministry of Agriculture, and thanks are due to C. D. Oxley, provincial bacteriologist, and F. W. Catton, assistant bacteriologist, for material advice and assistance.

24 Chesterton Hall Crescent, ERnest A. Gray Cambridge.

1Topley and Wilson, "Principles of Bacteriology and Immunity", 1 (3rd edit., London, 1948).

2 "Bergey's Manual of Determinative Bacteriology" (6th edit., London, 1948).

3.Stephenson, M., "Bacterial Metabolism" (London, 1943).

\section{Calanus finmarchicus and Related Forms}

THE copepod Calanus finmarchicus has been more thoroughly investigated than any other marine plankton organism. Some systematists have recognized in the material from European ${ }^{1}$ and eastern American waters ${ }^{2}$ two distinct species, $C$. finmarchicus and $C$. helgolandicus; but the distinguishing characters given have been too uncertain to receive universal acceptance ${ }^{3}$. In consequence, it has been assumed in most studies of the copepod-its population changes, physiology, behaviour, etc.- that the material used consists of a single species. Recently, it was pointed out that two forms, corresponding to the two species, could be readily distinguished in the female and copepodite stage $V$ by the structure of the basipod of the fifth swimming feet, though their status, whether species or sub-species, remained 